\section{PUBLIC HEALTH IN AMERICA.}

THE thirty-first annual report of the State Board of Health of Massachusetts, dealing with the work of the various departments during the year 1899 , has lately been issued. These reports are mainly known to this country in connection with the original investigations on the treatment of water and sewage which have for many years past formed an important feature of the work undertaken by this Board of Health.

The practical outcome of these researches is seen in the recommendations made by the Board to cities and towns, no less than 79 applications for advice regarding the establishment of systems of water supply, drainage and sewerage having been dealt with during the year, and the Board have the satisfaction of reporting that at the end of this period every city in the State and 132 out of a total of 321 towns were provided with public water supplies. If the death-rate from typhoid fever over a series of years be taken as an index of the sanitary condition of a community, then, indeed, the State of Massachusetts has just cause for congratulation on the results of the enlightened policy in regard to questions of hygiene which has been so persistently pursued by, and has so prominently distinguished, its officials.

In the years $187 \mathrm{I}-75$ the death.rate from typhoid fever in the cities, as well as in the State at large, was as high as 8.2 per 10,000. This figure has gradually been reduced to $2 \cdot 6$, and in the four years from 1896 to 1899 the rate has been further brought down to 2.4 per 10,000. Again, while in the period I $87 \mathrm{I}-75$ there was not a single city amongst the $3 \mathrm{I}$ in the State having a lower death-rate from typhoid fever than 2.7 per 10,000 , in 1899 there were 24 such cities. The most noteworthy improvement was that of Lawrence, where the typhoid death-rate fell from a mean of $11^{\cdot} 2$ per 10,000 in $1886-90$, and 7.7 in $1891-95$, to 2.5 in the four years $1896-99$, following the introduction of sand filtration of the water from the Merrimack river supplied to this city.

In regard to consumption, the Board is able to make a no less satisfactory report, the decline in mortality from this disease having continued with a fairly steady and uniform rate throughout the past fifty years, reaching in 189918.7 per 10,000 . In commenting upon this fact it is pointed out that it is between the ages of 15 and 60 that consumption is most fatal, and that in 1894 and 1895, out of 1000 deaths from all causes in Massachusetts between these ages 288 were due to tuberculosis, whilst in Paris the figures for the same period of life were 400 and in Vienna 459 , or nearly one-half of all the deaths at that age. Emphasis is laid upon the necessity for taking further precautions for the control and prevention of this most destructive disease, a sentiment which will be given practical effect to this year in England at the British Congress for the Prevention of Consumption, presided over by the King, to be held in London in July.

Massachusetts is, however, not the only State in America which is alive to the urgency of dealing effectively with this disease. Michigan, which supports a State Agricultural College, has recently issued a valuable Bulletin in which practical methods are suggested for combating this scourge, based upon careful scientific experiments. The writer of the Bulletin states that tuberculosis causes more than twice as many deaths in Michigan as any other single contagious disease, and Dr. Keen, of Rhode Island, has calculated that more than 100,000 persons annually die of consumption in America, and that at this rate out of the 70,000,000 people in the United States 10,000,000 are practically condemned to death through tuberculosis.

In discussing the unusual prevalence of small pox which has characterised the period covered by the report, a special table has been appended showing the comparative fatality of the vaccinated and unvaccinated respectively. This table is based upon carefully compiled statistics kept between the years 1885 and 1899 , and shows that the deaths from small pox among the vaccinated was $7^{\circ} 6$ per cent. and among the unvaccinated 26.0 per cent., or more than three times as great in the latter case during these fourteen years.

In the pathological department of the Board much attention has been bestowed upon the preparation of diphtheria antitoxin, and a large number of examinations were made for the verification of diphtheria germs. The work of this department has largely increased during the year, for considerable quantities of the antitoxin have been used for the immunisation of healthy persons who have been exposed to the infection of diphtheria, whilst at the Children's Hospital, an institution at which several hundred patients are annually received for treatment, medical and surgical, but not for infectious diseases, it has been the custom to immunise each patient with diphtheria antitoxin soon after admittance.

No reference is made to the preparation of antityphoid serum, neither, apparently, have any investigations been carried out with regard to it. Likewise we note that tetanus antitoxin is no longer prepared, the reason given for its discontinuance being that the demand for the serum was small and irregular, and its application usually delayed until the patient was past recovery.

An interesting section of the report deals with the results of the food and drug inspections. Although the use of preserva. tives or any foreign substance in milk is illegal, i ${ }^{\circ} 6$ per cent. of the samples examined contained a preservative, in the largest number of cases formaldehyde being employed, which is widely used in the United States under the name of "Freezine." A pamphlet setting forth the special advantages of this preservative states that "it is not an adulterant, that it immediately evaporates, so that it defies detection as soon as it has rendered all the bacteria inert, it is beneficial to the health of infants, many of whom have been saved from sickness and even death by a liberal use of 'Freezine' in the milk !"

Butter, we are informed, was specially tested for the presence of boracic acid in consequence of the alleged extensive use of this ingredient in Great Britain. None was found, which may be attributed to the custom which prevails to a much larger extent in America than in England of eating salt butter, in which case the use of an additional preservative would be superfluous.

The above brief sketch may give some idea of the general scope of the work undertaken by public boards of health in America. It serves to emphasise, perhaps, that Great Britain is still waiting for an Imperial Board of Health, and that what individual States in America can accomplish we as an Empire are powerless to achieve.

G. C. FrankLand.

\section{THE EXTENSION OF KNOWLEDGE.}

$A \mathrm{~N}$ inspiring address, dealing with the influence of universities upon national life, delivered at the Johns Hopkins University at the last commemoration day by Dr. D. J. Hill, assistant secretary of State, is published in one of the University Circulars just received. Students of human history well know that the pursuit of knowledge has been the fundamental factor of progress through many centuries. The earliest universities in Europe were associations of teachers and students with this aim, and they exerted a powerful influence upon society long before their existence was recognised by Church or State. "It is not too much to say," remarks Dr. Hill, "that the transformation of Europe which marks the distinction between medireval and modern times has been chiefly the work of the universities, for they have exercised the most potent influence upon social progress and popular liberty of any single class of human institutions." The spirit which has led to the establishment of so many institutions for higher education in the United States, by private munificence, seems to have been inherited from the Pilgrim Fathers. Even when the colony of Massachusetts numbered only four thousand, it was decided to found a college; but the resolution is less astonishing when it is remembered that among the first six hundred settlers one in every thirty was a graduate of Cambridge.

Dr. Hill concluded his address by referring to the changing conditions of life, and the need for all who are concerned with education to recognise their new obligations and make themselves equal to their modern mission. This part of the address is reprinted below.

"It is no longer a question of merely popular education, although that is always fundamental; it is a question of the higher and the highest education that confronts us now. We have passed the primary stage, the common schools are estab. lished, the colleges exist in sufficient numbers, and even universities do not need to be multiplied. We have sought the safeguard of liberty in the universal diffusion of knowledge, but it is not the mere rudiments that have saved us in any great emergency. In what crisis of diplomacy, in what complicated question of finance, in what quandary of economic policy; in what problem of constitutional interpretation have the elementary arts furnished saving knowledge to the nation? No, in

NO. I 648 VOL. 64 ] 